\title{
誘電体の光誘起協力現象
}

\author{
武貞 正樹 \\ 北海道大学大学院 理学研究院 ( $\bar{T} 060-0810$ 北海道札幌市北区北10条西8丁目)
}

\section{Photoinduced Cooperative Phenomena in Dielectrics}

\author{
Masaki TAKESADA \\ Department of Physics, Faculty of Science, Hokkaido University, 8 Nishi, Kitajujou, Kita-ku, Sapporo, Hokkaido 060-0810
}

(Received April 2, 2008)

\begin{abstract}
The laser-light refraction method has been performed to investigate the photo-induced cooperative phenomena of an early stage of ferroelasitc and ferroelectric domain formation on $\mathrm{KD}_{3}\left(\mathrm{SeO}_{3}\right)_{2}$ (DKTS) and Rochelle salt (RS) crystals. The refracted light intensity has been observed around the Curie point $\left(\mathrm{T}_{\mathrm{c}}\right)$. The each temperature dependence of the refracted light intensity under UV irradiation with wavelength of $266 \mathrm{~nm}$ for DKTS and $400 \mathrm{~nm}$ for RS with 130 fs pulse width shows drastic photoinduced effect in comparison with a non UV irradiation condition. The results clearly demonstrate that the pulsed UV laser irradiation produces a large effect in the embryonic fluctuation near $\mathrm{T}_{\mathrm{c}}$ as a photoinduced cooperative phenomenon.
\end{abstract}

Key Words: Photoinduced phase transition, Ferroelectrics, Ferroelastic domain, Embryonic fluctuation, Laser-light refraction method

1.はじめに

強誘電体の研究は1921年J. ValasekのRochelle塩における 強誘電性の発見にはじまり, 応用分野では圧電材料, 焦 電材料, 誘電材料, 非線形光学材料などその優れた機能 性が広く我々の生活で利用されている。最近では高周波 フィルタとして使われる弾性表面波 (Surface Acoustic Wave：SAW) デバイスや, 強誘電体の自発分極の反転を 利用した不揮発性の強誘電体ランダムアクセスメモリ (Ferroelectric Random Access Memory：FeRAM)など急速な デバイス技術の進歩には目を見張るものがある。基礎物 理学の視点において従来の誘電体研究分野では主に格子 系の議論が中心に行われ，誘電体に現れる様々な相転移 現象や，また広い意味での協力現象に関して研究が行わ れてきた.しかし最近になり誘電体においても電子系や 量子性が深く関係した強誘電性相転移現象が発見され誘 電体分野だけでなく他の研究分野においても強誘電性相 転移に関する研究が進められている。近年，レーザー技 術の進歩により紫外光領域における超短パルスレーザー 光が特別な技術を必要とせず扱えるようになり透明無機 物質群において，電子励起を伴った光励起をトリガーと し，協力的相互作用を介して巨視的な状態変化を引き起 こそうとする光誘起相転移現象への関心が高まってい る.

強誘電体の光照射効果に関して興味が持たれたのは今 から約半世紀前にさかのぼり，旧ソビエトのFridkinらの
研究グループを中心に研究がはじまっている．強誘電体 の光照射効果としては光照射による自発分極の変化，異 常光起電力効果，さらにフォトリフラクティブ効果など が報告されている。また強誘電性相転移に及ぼす光照射 効果としては, 強誘電体であるSbSIやチタン酸バリウム $\left(\mathrm{BaTiO}_{3}\right)$ で調べられたのがはじめで，誘電率測定による 相転移点のシフトや強誘電性ドメインの光による構造変 化が実験的に示された1-5)。そして観測された現象は現象 論に基づいて，光励起された非平衡状態にある電子が強 誘電体内の双極子相互作用に及ぼす遮蔽効果という視点 で議論がなされた6)。このような研究が 60 年代後半から 70年代に行われたが，当時のレーザー技術がまだ不十分 であったことから実験的にはあまり進歩せず，例えば光 によって強誘電性相転移をスイッチングさせるような光 誘起相転移現象までの実験的成果には結びつかなかっ た. 誘電体の光誘起相転移物質としては1990年に中性一 イオン性相転移を示す有機電荷移動錯体テトラチアフル バレンークロラニル (TTF-CA (tetrathiafulvalene-chloranil)) において，はじめて報告された7). TTF-CAにおいては光 励起により1つの光子で数百ユニットが変化し，イオン性 相の中に巨視的な中性相ドメインの生成が報告されてい る。TTF-CAの光誘起相転移現象に関してはこれまで広く 研究が行われ，詳しい解説記事があるのでそちらを参照 していただきたい8,9)。無機誘電体が示す強誘電性相転移 の一般的なイメージは光に対する感受性は低いものと考 えられている。しかし無機誘電体においても相転移点近 
傍でゆらぎや外力に対する感受性が発散的に大きくなる 状態にすると何が起こるであろうか. 実際に実験を行っ てみると光励起により絶縁体内にドープされた非平衡電 子や正孔に由来すると考元られる光誘起協力現象が秩序 初期形成過程 10,11) や誘電応答12-16) に観測される。本稿では 誘電体の相転移点近傍で長距離秩序が発生する際の秩序 初期形成過程に出現する光誘起協力現象の研究に関して 紹介したい。

\section{2. 秩序初期形成過程測定のためのレーザー屈折法}

強誘電強弾性相転移を示すロッシェル塩 (RS (Rochelle Salt)) と常誘電強弾性相転移を示す $\mathrm{KD}_{3}\left(\mathrm{SeO}_{3}\right)_{2}(\mathrm{DKTS})$ の透明無機誘電体結晶に扔いて, 相転移点直上のまさに 秩序化が始まろうとする温度領域で観測される光誘起効 果について述べる.RSとDKTSは共に斜方晶構造から単 斜晶構造へ弾性的自発歪を伴った強弾性相転移17)を示 し，相転移の秩序変数と歪が双一次結合している物質で ある18,19)．Fig. 1に強弹性相転移の概念図を示す．一方， 両物質は対称中心の有無という点で異なりRSは相転移点 $T_{c}=297 \mathrm{~K}$ を挟む高温相と低温相 (強弾性相)の両相で対 称中心を持たず低温相で強誘電性を示し, DKTSは $\mathrm{T}_{\mathrm{c}}=$ $302 \mathrm{~K}$ 挟む両相で対称中心を持ち低温相においても常誘 電性状態にある。

強弹性相ではFig. 1に示すようにエネルギー的に等価な 2つの領域で構成される強弾性ドメイン構造を形成して いる. 隣り合うドメインの屈折率楕円体はFig. 2 a) に示 すように棈円体の主軸が $\phi$ 傾いている。従って強弾性ド

(a)

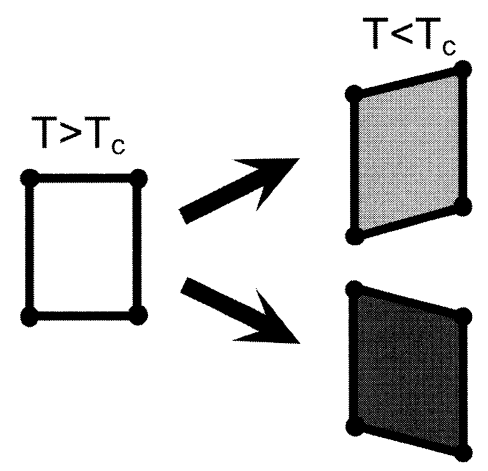

(b)

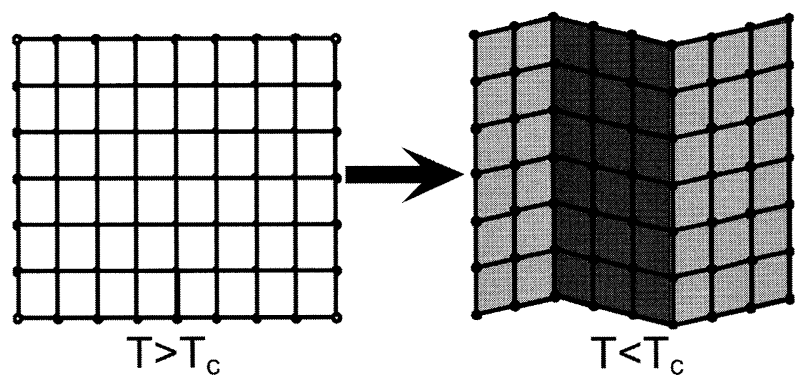

Fig. 1 Schematic illustration of ferroelastic phase transition. (a) The uniaxial projection of orthorhombic structure above $\mathrm{T}_{\mathrm{c}}$ and monoclinic structure below $\mathrm{T}_{\mathrm{c}}$. (b) The ferroelastic domain structure appeared in ferroelastic phase below $\mathrm{T}_{\mathrm{c}}$. (a)

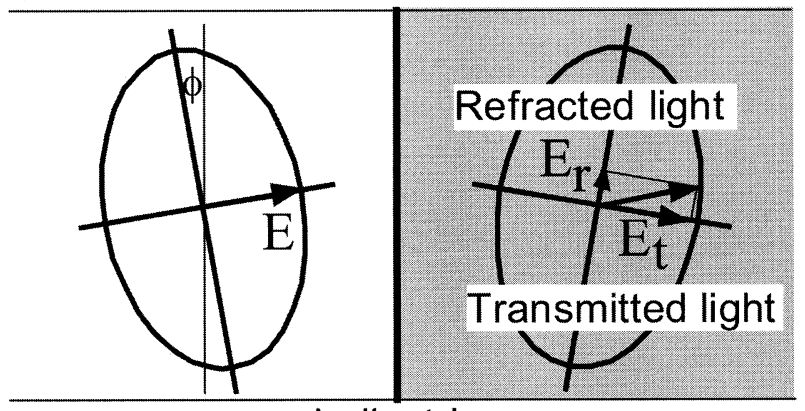

Indicatrix

(b) Transmitted light Refracted light

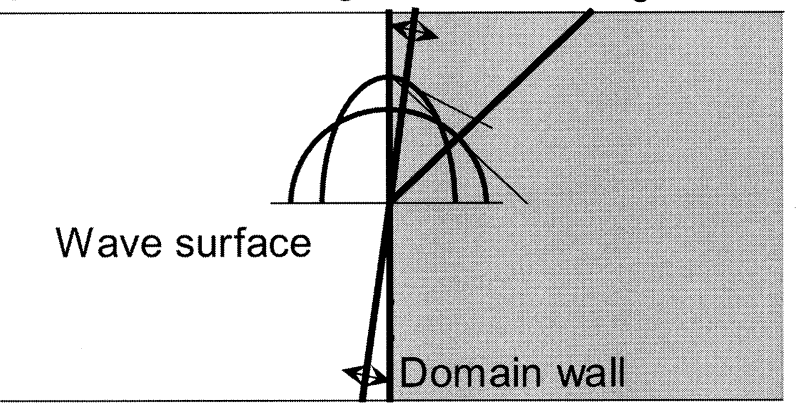

Fig. 2 Transmitted and refracted light from the ferroelastic domain boundary. (a) The relation of each polarization direction among the incident, transmitted, and refracted lights is obtained from the refractive indicatrices in the ferroelastic domains. (b) The beam directions of transmitted and refracted light obtained from the Huygens construction on a domain wall.

メイン構造を形成した結晶中にFig. 2 b)のように水平偏 光のレーザー光を入射するとドメイン壁を境に水平偏光 の透過光と垂直偏光の屈折光に分離する. (Laser Light Refraction(LLR) 法) ${ }^{20)}$ 屈折光はドメイン形成に伴って出 現することからこの屈折光をプローブとすることで強弾 性ドメイン構造の変化を高感度かつ非接触に観測するこ とができる21). LLR法により光励起下で強誘電性・強弾 性ドメイン初期形成過程を測定した光学系をFig. 3に示し た。ここでは再生増幅フェムト秒パルスTi:Sapphireレー ザーにより得られた波長 $800 \mathrm{~nm}$ 基本波でSHGもしくは THGユニットを用いて第2，3高調波光(波長はそれぞれ $400 \mathrm{~nm}, 266 \mathrm{~nm})$ を発生させ, パルス幅 $130 \mathrm{fs}$, 繰り返し $1 \mathrm{kHz}, 1$ パルス当たり $4 \mu \mathrm{J}$ (平均パワー $4 \mathrm{~mW}$ )のレーザー 光をUVパルス励起光源とした. また屈折光を得るため プローブ光にはHe-Neレーザー(波長 $632 \mathrm{~nm}, 0.5 \mathrm{~mW}$ )を 用いた。さらに励起密度に依存した変化を調べるため, パルス励起との比較対照実験に連続 $(\mathrm{CW})$ 発振の $\mathrm{He}-\mathrm{Cd}$ レーザー(波長 $325 \mathrm{~nm}, 5 \mathrm{~mW}$ )をCW-UV励起光源として 用いた。

\section{3. 強誘電性・強弾性秩序初期形成過程の光誘起効果}

強弾性相転移を示すDKTSの屈折光強度の温度依存性を Fig. 4に示す10). 白丸 (O) はUV励起光を試料へ照射しない 


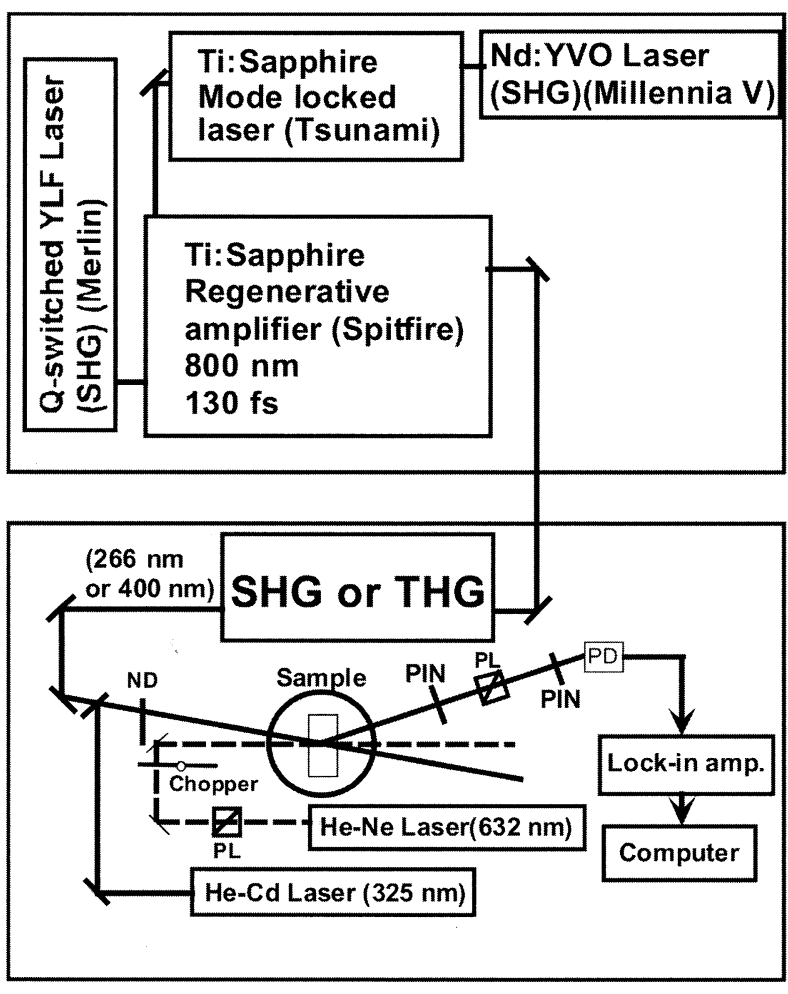

Fig. 3 Experimental system for the laser-light refraction method under an UV irradiation.

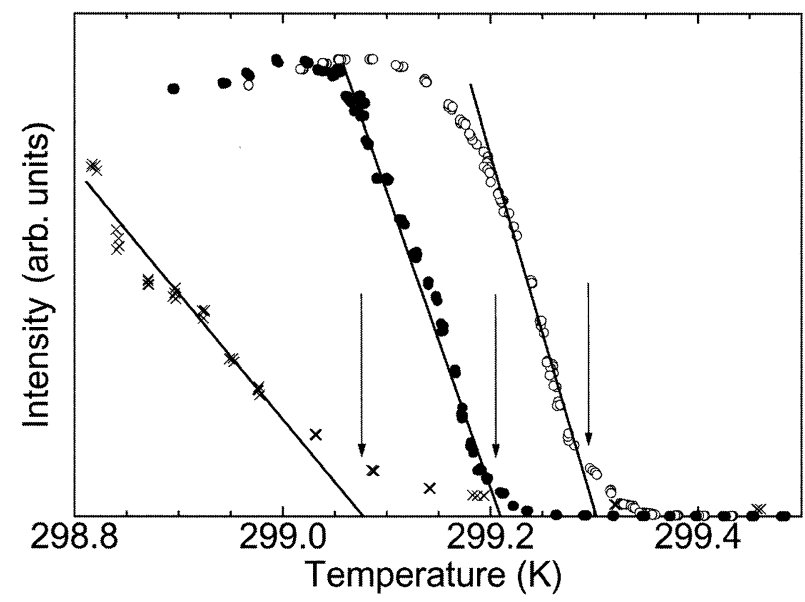

Fig. 4 Temperature dependence of refracted light intensity on ferroelastics $\mathrm{KD}_{3}\left(\mathrm{SeO}_{3}\right)_{2}$ (DKTS). The arrows indicate the Curie point $T_{c}$ obtained from the each experimental condition. ${ }^{10)}$

実験条件におけるレーザー屈折光強度の温度依存性を示 す。屈折光強度の興味ある特徵は $\mathrm{T}_{\mathrm{c}}$ で直ちにゼロになるの ではなく, Fig. 5の log プロット表示でより明確になるよう に約 $\mathrm{T}_{\mathrm{c}}+1 \mathrm{~K}$ まて強度が確認され連続的に減少する様子が 観測される。この $\mathrm{T}_{\mathrm{c}}$ 直上に測定される非常に強度の小さい 屈折光は, 強弾性的な巨視的秩序形成化に由来して物質 中のゆらぎが相転位直上で非常に大きくなっていること を(強弾性秩序初期形成過程)を示している. Fig. 4の黒丸 （○）はCW-UV励起を行った場合の屈折光強度の温度依存 性であり，クロス $(\mathrm{x})$ は波長 $266 \mathrm{~nm}$ のフェムト秒パルス レーザー光を用いてUVパルス励起を行った場合の結果で

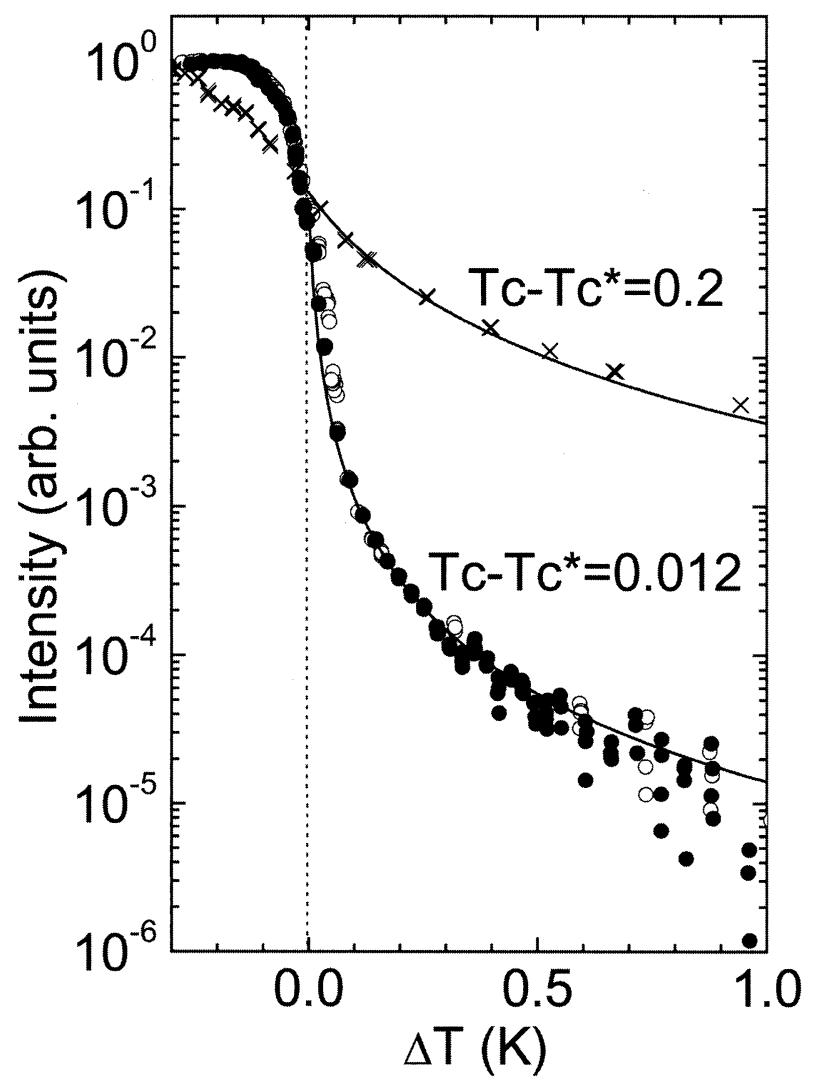

Fig. 5 Logarithmic plot of the refracted light intensity from $\mathrm{KD}_{3}\left(\mathrm{SeO}_{3}\right)_{2}$ (DKTS) around $\mathrm{T}_{\mathrm{c}}$. The solid curve is obtained from the function, $I=\alpha\left(T-\left(T_{\mathrm{c}}-\Delta T_{\mathrm{c}}\right)\right)^{-2}$, $\Delta T_{\mathrm{c}}=0.2 \mathrm{~K}$ and $0.012 \mathrm{~K}$, respectively. ${ }^{11)}$

ある．励起光を照射しない場合 $(\bigcirc)$ とCW-UV励起光を照 射した場合 $\left(\right.$ ) では $\mathrm{T}_{\mathrm{c}}$ が約 $0.1 \mathrm{~K}$ 低温側へシフトする他は 顕著な違いは観測されない。この相転移点のシフトはUV 光よって励起された非平衡電子による協力的相互作用の 遮蔽効果と6)，UV光を照射した際にエネルギーの一部が 熱に変換され局所的温度上昇が発生した結果，試料と温 度センサーの読み值に差が生じる加熱効果の2つの原因に よるものと考えられる.

次にUVパルス励起を行った結果について述べる。

Fig. 4, Fig. 5に示すようにUV励起を行った場合 $(x)$ には 励起光を照射しない場合 $(O)$ と比較し顕著なUVパルス 光の照射効果が観測される. 特徵的な $2 つ の$ 光誘起効果 について述べる，先ず一つ目は，得られた光誘起効果は 相転移点のシフトがCW-UV励起の場合と比較しても, さ らに低温側へシフトする点にある。ここではUVパルス励 起には平均パワー $4 \mathrm{~mW}$ 用い, CW-UV励起には $5 \mathrm{~mW}$ 用いているため, 励起光平均パワーの大小関係から加熱 効果や励起された非平衡電子による遮蔽効果はCW-UV励 起の場合に，より大きくなると考えられる。しかし得ら れた結果はUVパルス励起を行った方が大きな $\mathrm{T}_{\mathrm{c}}$ のシフト が測定さており，高密度励起の場合には加熱効果や非平 衡電子の遮蔽効果では説明できない光誘起効果が強弾性 秩序形成過程に現れる. 二つ目の光誘起効果はFig. 5 に示 されるように $\mathrm{T}_{\mathrm{c}}$ 直上の秩序初期形成過程に観測され，屈性 光強度の顕著な増大が測定される。 $\mathrm{T}_{\mathrm{c}}$ 以上の温度領域で屈 
折光強度の温度依存性がどのような関数で記述できるか を見るため, 関数 $I=\alpha\left(T-\left(T_{\mathrm{c}}-\Delta T_{\mathrm{c}}\right)\right)-2 て ゙ \Delta \mathrm{T}_{\mathrm{c}}$ を変数として フィットしてみると実線のような結果が得られる. 励起 光を照射しない場合 $(\bigcirc)$ には $\Delta \mathrm{T}_{\mathrm{c}}=0.012 \mathrm{~K} て ゙$ 実験結果をよ く再現する。またCW-UV励起の場合 $(\mathbf{O})$ にもほほ等しい 值を示す.一方, UVパルス励起を行った場合 $(x)$ には $\Delta \mathrm{T}_{\mathrm{c}}$ $=0.2 \mathrm{~K}$ が得られる. $\Delta \mathrm{T}_{\mathrm{c}}$ の大きさは結晶中の空間変調の度 合いを示しており実験結果はUVパルス励起による高密度 励起により空間変調が誘起されたことを示している。

強誘電性相転移を示す RSの屈折光強度の温度依存性を Fig. 6に示す. 白丸 $(\bigcirc)$ は励起を行わない場合，黒丸 は波長400 nmのフェムト秒パルスレーザー光を用いてUV パルス励起を行った場合である. RSにおいてもDKTSと 同様に $\mathrm{T}_{\mathrm{c}}$ 直上で屈折光強度の増大が光誘起効果として観 測される。ここで励起を行わない場合の結果をRSの場合 とDKTSの場合とで注意して比較すると, RSの屈折光強 度の温度依存性は, 強誘電性相の屈折光強度の值に対し て約 3 桁程度の減少に留まり, $\mathrm{T}_{\mathrm{c}}$ 以上の屈折光強度が DKTSと比較し大きいように見える。しかしこれは試料の 表面が䢃開面で得られたDKTSと研磨面のRSで違いが生 じたもので, 研磨面の僅かな傷による散乱光が屈折光の バックグランドに加わるためである．もしRSにおいて DKTS 同様の試料表面が得られるならばDKTSと定性的 に等しい結果が得られるであろう。つまり強誘電体RSと 強弾性体DKTSにおいて共に $\mathrm{T}_{\mathrm{c}}$ 直上でゆらぎや感受性が発 散的に増大する秩序初期形成過程において光により協力 現象が顕著な変化を示す光誘起協力現象が観測される.

\section{4. 誘電体における光誘起協力現象のメカニズム}

誘電体において観測された光誘起協力現象の発現機構 としてどのようなモデルが考えられるだろうか. 誘電体 にバンドギャップを超えるエネルギーで光励起を行うと 価電子带から伝導带へ電子が励起される。この励起され た非平衡電子には様々な緩和プロセスが予想される。例 えばFig. 7に示すように伝導帯で長い寿命をもち結晶全体 に広がって自由に動く伝導電子となるもの，また電子一 正孔対を生成して周りの分極も引きずりポーラロンを形

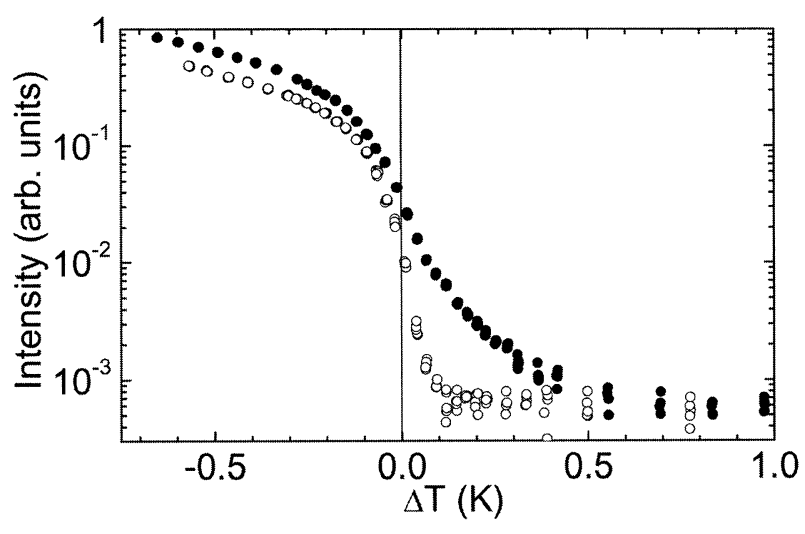

Fig. 6 Temperature dependence of the refracted light intensity of ferroelectric Rochelle salt (RS). ${ }^{11)}$

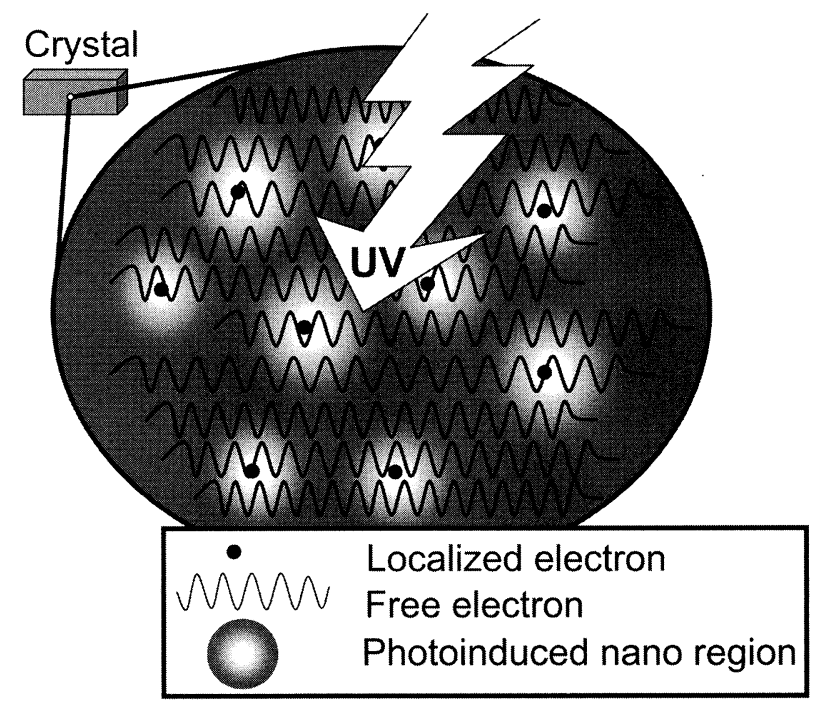

Fig. 7 Schematic illustration of photoinduced state in the crystal.

成するもの, 伝導带を経て不純物準位や欠陥準位の局在 状態へトラップされ，またそこから基底状態へ緩和する もの, またさらに非平衡電子が過渡的局在状態を経る間 に格子系と相互作用し, 光誘起ナノ領域が形成すること などが考えられる．実際の系ではこれらの中の一つが実 現されるのではなく複数のプロセスが同時に起こり複雑 な現象を発現すると予想される.RSやDKTSの秩序状態 の初期形成過程はUV照射によりドメイン形成に由来する 屈性光強度が増加することから, $\mathrm{T}_{\mathrm{c}}$ 直上において光励起 により秩序形成が促されたことを示している。このよう な特徵をもつ光誘起協力現象のメカニズムについて一つ のモデルを考えてみる。秩序相のドメイン構造は結晶に 内在するランダムフィールドに由来した空間変調の影響 を強く受ける。ここで励起された非平衡電子がもたらす ポーラロン形成や局在電子の影響で, この空間変調の振 幅が増加し秩序形成を促進したものと考えられる。

\section{5. まとめ}

レーザー屈折法を用いると高感度かつ非接触に相転移 近傍の秩序初期形成過程を観測することが可能になる. 本研究では, この手法を用いて一般的な無機強誘電体や 無機強弾性体において顕著な光誘起協力現象が秩序初期 形成過程に出現することを示した，無機誘電体における 光誘起協力現象はここで紹介した $2 つ$ 物質だけでなく, ペロフスカイト型酸化物である量子常誘電体 $\mathrm{SrTiO}_{3} や$ $\mathrm{KTaO}_{3}{ }^{12-16)}$ ，またFeRAM材料として期待される $\mathrm{Bi}$ 層状ぺ ロフスカイトについても報告されており, 今後, 様々な 無機誘電体 ·強誘電体物質で新奇光誘起協力現象の発見 が期待される. 誘電体の光誘起協力現象は光によって価 電子帯から伝導帯へ励起された非平衡電子状態が相転移 近傍に現れる“ゆらぎに変化をもたらすことで出現したと 考えられる. 強誘電体のような凝縮系において, 特に相 転移点近傍では光励起による非平衡電子状態の影響で複 合的現象を生み出すことが予想される. そのため単純に 
は現象が扱えないことを注意してほしい。ある一つの系 で光励起を行った際にも非平衡電子は上述したように多 彩な電子状態をとるであろう。例えば遍歴状態の電子は 伝導性に寄与し, 局在した電子やそれと結合した格子系 は誘電性に寄与するであろう。また空間的な状態にも注 意が必要で, 光によって作られた励起状態は多彩な電子 状態の影響でナノスケールからマイクロスケールに渡る 階層的な不均一構造の形成をするかもしれない。この場 合は誘電率一つをとってみても, ナノスケール不均一状 態における定義は厳密なものがなく，このような不均一 状態の誘電率を例えばMaxwell-Wagner的に巨視的な伝導 体領域と絶縁体領域との単純な和で簡単に議論できるで あろうか. 従来の概念を適応しようとすると様々に矛盾 が生じる。

上に光誘起協力現象の例として示した誘電体は全て2次 相転移を示す物質で行われている。これは物質のゆらぎ や感受率が発散的に大きくなることを利用し, 僅かな光 の外力が協力現象に影響を及ぼすと考えたためである. 今後, 無機強誘電体で光による強誘電性相転移のスイッ チング現象, すなわち光誘起強誘電性相転移を実現する ためには，相転移に温度履歴を示し2相共存状態が可能な 1次相転移で研究を行う必要がある. 誘電体の協力現象に おける電子系の寄与に関する研究はこれまで不十分で あったように思われる。 今後, 誘電体における光誘起協 力現象の解明が進むことで, 誘電体研究がさらに一歩前 進するものと期待する.

\section{謝 辞}

本研究を進めるにあたり腰原 伸也教授, 木下修一教 授, 上江洲由晃教授, 那須 奎一郎教授, 小川哲生教授, 石川 忠彦助教, 近藤 憲治講師, 八木 駿郎教授, 小野寺 彰教授から共同研究や有益な議論を得たことに感謝いた
します。本研究の一部は日本学術振興会科学研究補助金 (基盤研究 $(\mathrm{B})$ ) (17340088)，（基盤研究 $(S)$ ) (17104004) 北 海道大学 21 世紀COEプログラム「トポロジー理工学の創 成」より経済的援助を受けたものでありここに感謝いたし ます。

\section{参考文献}

1) L. M. Belyaev, I. I. Groshik, V. A. Lyakhovitskaya, V. N. Noscov, and V. M. Fridkin: JETP Lett. 6 (1967) 481.

2) B. P. Grigas, I. P. Grigas, and R.P.Belyatskas: Soviet Phys. Solid State 9 (1967) 1203.

3) V. M. Fridkin and I. I. Groshik: Appl. Phys. Lett. 10 (1967) 354.

4) G. Godefroy, P. Jullien, and L. Cai: Ferroelectrics 13 (1976) 303.

5) T. R. Volk, A. A. Grekov, N. A. Kosonogov, A. I. Rodin, and V. M. Fridkin: Kristallografiya 16 (1971) 241.

6) V. M. Fridkin: Photoferroelectrics (Springer-Verleg, Berlin, 1979).

7) S. Koshihara, Y. Tokura, T. Mitani, G. Saito, and T. Koda: Phys. Rev. B 42 (1990) 6853.

8）腰原伸也, 十倉好紀：固体物理 27 (1992) 367.

9) K. Nasu: Photoinduced Phase Transitions (World Scientific, 2003).

10) M. Takesada and S. Koshihara: Ferroelectrics 264 (2001) 309.

11）武貞 正樹：レーザー研究 36 （2008） 357.

12) M. Takesada, T. Yagi, M. Itoh, and S. Koshihara: J. Phys. Soc. Jpn. 72 (2003) 37.

13) T. Hasegawa, S. Mouri, Y. Yamada, and K. Tanaka: J. Phys. Soc. Jpn. 72 (2003) 41.

14) K. Nasu: Phys. Rev. B 67 (2003) 174111.

15) T. Ishikawa, M. Kurita, H. Shimoda, Y. Sakano, S. Koshihara, M. Itoh, and M. Takesada: J. Phys. Soc. Jpn. 73 (2004) 1635.

16) 武貞 正樹, 八木 駿郎, 伊藤 満, 石川忠彦, 腰原 伸也 : 固 体物理 40 (2005) 113.

17）強弾性相転移の一般的紹介記事として, 中村輝太郎：固体物 理 14 (1979) 63.

18) H. Mueller: Phys. Rev. 57 (1940) 829.

19) Y. Makita, F. Sakurai, T. Osaka, and I. Tatsuzaki: J. Phys. Soc. Jpn. 42 (1977) 518.

20) T. Tsukamoto, J. Hatano, and H. Futama: J. Phys. Soc. Jpn. 53 (1984) 838

21) S. Kinoshita, S. Kutsuzawa, Y. Shimada, and T. Yagi: Phys. Rev. B 50 (1994) 5834. 